\title{
Primeira edição do Formulário Nacional aprovada
}

First edition of the $N$ ational Form approved

Agência Nacional de Vigilância Sanitária - Anvisa

Foi aprovada a primeira edição do Formulário Nacional, código oficial brasileiro onde estão inscritas formulações farmacêuticas oficiais, estáveis, de uso consagrado internacionalmente. O objetivo principal do Formulário é a padronização dos medicamentos, com o intuito de assegurar a sua qualidade.*

A obra contêm informações de 82 medicamentos de uso corrente, como o leite de magnésia, usado como antiácido e laxante suave, e o sulfato ferroso, para tratamento de anemia. Além das fórmulas, a obra contêm os sinônimos usados para referência ao produto; a forma farmacêutica (solução ou creme, por exemplo); orientações para o preparo; informações sobre embalagem e armazenamento; advertências; indicações terapêuticas e modo de usar. Além disso traz também informações sobre 23 bases para preparo de formulações e de 12 soluções auxiliares.

As fórmulas contidas no código são de cunho social e irão proporcionar aos farmacêuticos e à indústria farmacêutica meios de melhor atender às necessidades da população. Todas as farmácias e os laboratórios farmacêuticos que manipulam ou fabricam os produtos constantes do Formulário Nacio- nal deverão ter pelo menos um exemplar atualizado.

Como essas formulações são tradicionais e não representam riscos para a saúde pública, a Anvisa estuda a possibilidade de definição de regras para a isenção de registro desses medicamentos, se forem obedecidos todos os requisitos contidos no Formulário Nacional. Essa medida vai simplificar o trâmite de exigências técnicas entre a Agência e o setor regulado, pois o produto poderia ser comercializado logo após a empresa apresentar notificação à Agência.

\section{Histórico}

Embora tenha sido citado em documentos oficiais desde 1955, o código jamais foi publicado. A partir de 2000, a Anvisa articulou-se com diversos segmentos da área farmacêutica dando início à elaboração do Formulário. Essa primeira versão está sendo revisada pela Editora Anvisa e deve ser publicada ainda este ano.

OFormulário Nacional foi elaborado pela Subcomissão do Formulário Nacional. Esse grupo de trabalho integra a Comissão Permanente de Revisão da Farmacopéia Brasileira (CPRFB), entidade vinculada à Anvisa.
Correspondência para/ Correspondence to: ANVISA - Assessoria de Imprensa SEPN 515 Bloco B - Edifício Ômega $1^{\circ}$ subsolo

70770-502 Brasília, DF

E-mail: imprensa@anvisa.gov.br

Site: www.anvisa.gov.br
Texto de difusão técnico-científica da Anvisa.

*Resolução no222 de 29/7/2005. Disponível em: http://e-legis.bvs.br/leisref/public/showAct.php?id=18369\&word= 